\title{
PENERAPAN METODE PEMBELAJARAN KOOPERATIF MODEL TGT UNTUK MENINGKATKAN HASIL BELAJAR IPS SISWA KELAS IX G SEMESETER I SMP NEGERI 1 KEDUNGGALAR
}

\author{
Endro Sutarman \\ Guru SMP N I Kedunggalar Ngawi \\ Email: endro.sutarman@gmail.com
}

\begin{abstract}
Abstrak
Pembelajaran IPS terpadu merupakan sebuah kajian yang memiliki objek abstrak, sehingga beberapa siswa khususnya di kelas IX G SMP N I Kedunggalar memiliki kesulitan dalam mencerna materi yang disampaikan. Oleh karena itu guru perlu kreatf dalam membuat pembelajaran yang menarik bagi siswa. Salah satu yang dilakukan guru adalah menerapkan model pembelajaran kooperatif jenis model TGT (Team Games Tournament). Penelitian ini merupakan Penelitian Tindakan Kelas dengan 3 siklus. Setiap siklus meliputi rencana, tindakan, pengamatan dan refleksi. Subyek penelitian adalah siswa kelas IX G SMP Negeri 1 Kedunggalar sebanyak 34 orang. Pembelajaran dengan kooperatif model TGT memiliki dampak positif dalam meningkatkan hasil belajar siswa dalam setiap siklus, yaitu 61,7\%, 88,5\%, dan 97,05\%.Penerapan metode pembelajaran kooperatif model TGT dapat meningkatkan motivasi belajar siswa, ditunjukan hasil wawancara dengan siswa, rata-rata jawaban menyatakan bahwa siswa tertarik dan berminat dengan metode pembelajaran kooperatif model TGT.
\end{abstract}

Kata kunci: Pembelajaran Kooperatif Model TGT, Hasil Belajar IPS

\begin{abstract}
Integrated social studies learning is a study that has abstract objects, so that some students, especially in class IX G of SMP N I Kedunggalar have difficulties in digesting the material presented. Therefore teachers need to be creative in making learning interesting for students. One of the things the teacher did was to apply the cooperative learning model of the TGT model (Team Games Tournament). This study is a Classroom Action Research with 3 cycles. Each cycle includes plans, actions, observations and reflections. The research subjects were $34 \mathrm{G}$ grade students of Ngeri 1 Kedunggalar Middle School with 34 people. Cooperative learning of the TGT model has a positive impact in improving student learning outcomes in each cycle, namely 61.7\%, 88.5\%, and 97.05\%. The application of the cooperative learning method of the TGT model can increase student learning motivation, indicated by the results of interviews with students, the average answer states that students are interested and interested in the cooperative learning method of the TGT model.
\end{abstract}

Keywords: Cooperative Learning TGT Model, Social Studies Learning Outcomes

\section{PENDAHULUAN}

IPS Terpadu merupakan suatu bahan kajian yang memiliki objek abstrak dan dibangun melalui proses penalaran deduktif, yaitu kebenaran suatu konsep diperoleh sebagai akibat logis dari kebenaran sebelumnya sudah diterima, sehingga keterkaitan antar konsep dalam IPS Terpadu bersifat sangat kuat dan jelas. Dalam 
pembelajaran IPS Terpadu agar mudah dimengerti oleh siswa, proses \{penalaran deduktif untuk menguatkan pemahaman yang sudah dimiliki oleh siswa. Tujuan pembelajaran IPS Terpadu adalah melatih cara berfikir secara sistematis, logis, kritis, kreatif dan konsisten.

Pembelajaran kooperatif lebih menekankan interaksi antar siswa. Dari sini siswa akan melakukan komunikasi aktif dengan sesama temannya. Dengan komunikasi tersebut diharapkan siswa dapat menguasai materi pelajaran dengan mudah karena "siswa lebih mudah memahami penjelasan dari kawannya dibanding penjelasan dari guru karena taraf pengetahuan serta pemikiran mereka lebih sejalan dan sepadan". (Muhammad, 2005).

Berdasarkan paparan tersebut diatas maka peneliti melakukan penelitian dengan judul "Upaya Meningkatkan Hasil Belajar IPS Terpadu Melalui Metode Pembelajaran Kooperatif Model TGT (Team Games Tournament) Siswa Kelas IX G Semester I SMP Negeri 1 Kedunggalar Tahun Pelajaran 2015/2016", sebagai alternatif untuk meningkatkan hasil belajar IPS Terpadu.

Adapun tujuan dari penelitian adalah untuk meningkatkan hasil belajar siswa melalui metode pembelajaran kooperatif model TGT pada Siswa Kelas IX G Semester I SMP Negeri 1 Kedunggalar Tahun Pelajaran 2015/2016 ? Mengetahui pengaruh hasil siswa belajar setelah diterapkan metode pembelajaran kooperatif model TGT pada Siswa Kelas IX G Semester I SMP Negeri 1 Kedunggalar Tahun Pelajaran 2015/2016.

\section{KAJIAN LITERATUR Pembelajaran Kooperatif}

Pembelajaran kooperatif adalah suatu pengajaran yang melibatkan siswa untuk bekerja dalam kelompok-kelompok untuk menetapkan tujuan bersama. (Felder, 1994) dalam Muhammad (2005). Wahyuni (2001) menyebutkan bahwa pembelajaran kooperatif merupakan strategi pembelajaran dengan cara menempatkan siswa dalam kelompokkelompok kecil yang memiliki kemampuan berbeda. Pembelajaran kooperatif mempunyai unsur-unsur yang perlu diperhatikan. Unsur-unsur tersebut sebagai berikut:

a. Para siswa harus memiliki persepsi bahwa mereka "tenggelam atau berenang bersama".

b. Para siswa memiliki tanggungjawab terhadap siswa lain dalam kelompoknya, disamping tanggungjawab terhadap dirinya sendiri, dalam mempelajari materi yang dihadapi.

c. Para siswa harus berpandangan bahwa mereka semuanya memiliki tujuan yang sama.

d. Para siswa harus membagi tugas dan berbagai tanggungjawab sama besarnya diantara para anggota kelompok.

e. Para siswa akan diberikan satu evaluasi atau penghargaan yang akan ikut berpengaruh terhadap evaluasi seluruh anggota kelompok.

f. Para siswa berbagi kepemimpinan sementara mereka memperoleh keterampilan bekerjasama selama belajar.

g. Para siswa akan diminta mempertanggungjawabkan secara individual materi yang ditangani dalam kelompok kooperatif.

Berdasarkan unsur-unsur dalam pembelajaran kooperatif, Johnson, Johnson dalam Djamarah, Syaiful Bahri (2000) menyebutkan peranan guru dalam pembelajaran kooperatif sebagai berikut:

- Menentukan objek pembelajaran 
- Membuat keputusan menempatkan siswa dalam kelompok-kelompok belajar sebelum pembelajaran dimulai.

- Menerangkan tugas dan tujuan akhir pada siswa.

- Menguasai kelompok belajar dan menyediakan keperluan tugas.

- Mengevaluasi prestasi siswa dan membantu siswa dengan cara mendiskusikan cara kerjasama.

Pembelajaran Kooperatif Dengan Model TGT (Team Games Tournament)

Soekamto, Toeti (1997) menjelaskan langkah-langkah dalam pembelajaran kooperatif mode TGT sebagai berikut:

1. Kelompokkan siswa dengan masingmasing kelompok terdiri dari tiga sampai dengan lima orang. Anggotaanggota kelompok dibuat heterogen meliputi karakteristik kecerdasan, kemampuan awal IPS, motivasi belajar, jenis kelamin.

2. Kegiatan pembelajaran dimulai dengan presentasi guru dalam menjelaskan pelajaran berupa paparan masalah, pemberian data, pemberian contoh. Tujuan presentasi adalah untuk mengenalkan konsep dan mendorong rasa ingin tahu siswa.

3. Pemahan konsep dilakukan dengan cara siswa diberi tugas-tugas kelompok. Mereka boleh mengerjakan tugas-tugas tersebut secara serentak atau saling bergantian menanyakan kepada temannya yang lain atau mendiskusikan masalah dalam kelompok atau apa saja untuk menguasai materi pelajaran tersebut. Para siswa tidak hanya dituntut untuk mengisi lembar jawaban tetapi juga untuk mempelajari konsepnya. Anggota kelompok diberitahu bahwa mereka dianggap belum selesai mempelajari materi sampai semua anggota kelompok memahami materi pelajaran tersebut.

4. Siswa memainkan pertandinganpertandingan akademik dalam tournament mingguan dan teman sekelompoknya tidak boleh menolong satu sama lain. Pertandingan individual ini bertujuan untuk mengetahui tingkat penguasaaan siswa terhadap suatu konsep dengan cara siswa diberikan soal yang dapat diselesaikan dengan cara menerapkan konsep yang dimiliki sebelumnya.

5. Hasil pertandingan selanjutnya dibandingkan dengan rata-rata sebelumnya dan poin akan diberikan berdasarkan tingkat keberhasilan siswa mencapai atau melebihi kinerja sebelumnya. Poin ini selanjutnya dijumlahkan untuk membentuk skor kelompok.

6. Setelah itu guru memberikan pernghargaan kepada kelompok yang terbaik prestasinya atau yang telah memenuhi kriteria tertentu. Penghargaan disini dapat berupa hadiah, sertifikat, dan lain-lain.

Gagasan utama dibalik model TGT adalah untuk memotivasi para siswa untuk mendorong dan membantu satu sama lain untuk menguasai keterampilan-keterampilan yang disajikan oleh guru. Jika para siswa menginginkan agar kelompok mereka memperoleh penghargaan, mereka harus membantu teman sekelompoknya mempelajari materi yang diberikan. Mereka harus mendorong teman meraka untuk melakukan yang terbaik dan menyatakan suatu norma bahwa belajar itu merupakan suatu yang penting, berharga dan menyenangkan. Dengan pembelajaran model ini siswa harus saling mengisi kekurangan antara satu dengan yang lainnya, dan mereka harus saling bersaing secara sehat antar 
kelompok untuk menjadikan yang terbaik diantara beberapa kelompok yang dibentuk.

\section{Kerangka Berfikir}

Pelaksanaan proses pembelajaran secara konvensional melalui metode klasikal membawa dampak kejenuhan bagi siswa sehingga, kualitas pembelajaran yang tercipta akan terasa kurang. Dari kurangnya kualitas pembelajaran yang dikarenakan efek dari tidak adanya motivasi belajar siswa tersebut membawa dampak kurang meningkatnya hasil belajar atau tingkat pemahaman siswa terhadap materi pelajaran yang disampaikan oleh guru.

Pesaingan dan kerja kelompok merupakan suplemen untuk mengatasi rendahnya motivasi tersebut, karena dengan kerja sama sesuatu yang dirasakan berat akan menjadi ringan, begitu pula dengan persaingan dengan model tournament maka setiap kelompok harus memperebutkan suatu supremasi yang menjadikan lambang kebanggaan jika kelompok mereka menjadi yang terbaik dari kelompok-kelompok yang lain. Hal inilah yang akan dimanfaatkan oleh peneliti untuk mengatasi rendahnya motivasi belajar siswa dengan menciptakan suasana belajar yang aktif, kreatif, menyenangkan namun tetap efektif untuk meningkatkan pemahaman siswa terhadap suatu materi pelajaran. Yang mana pemikiran tersebut akan dituangkan dalam bentuk pembelajaran kooperatif model TGT (Team Games Tournament).

\section{Hipotesis Tindakan}

Berdasarkan pada kerangka pemikiran tersebut maka dalam penelitian ini penulis dapat memberikan hipotesis tindakan sebagai berikut "Melalui metode pembelajaran kooperatif model TGT (Team Game Tournament) akan dapat meningkatkan motivasi dan kualitas belajar Siswa Kelas IX G Semester I SMP Negeri 1 Kedunggalar Tahun Pelajaran 2015/2016.

\section{METODE PENELITIAN Jenis penelitian}

Penelitian ini merupakan penelitian tindakan (action research), karena penelitian dilakukan untuk memecahkan masalah pembelajaran di kelas. Penelitian ini juga termasuk penelitian deskriptif, sebab menggambarkan bagaimana suatu teknik pembelajaran diterapkan dan bagaimana hasil yang diinginkan dapat dicapai.

\section{Tempat Penelitian}

Tempat penelitian adalah tempat yang digunakan dalam melakukan penelitian untuk memperoleh data yang diinginkan. Penelitian ini bertempat di SMP Negeri 1 Kedunggalar Tahun Pelajaran 2015/2016.

\section{Subyek Penelitian}

Subyek penelitian adalah siswa-siswi kelas IX G yang berjumlah 34 orang pada semester I SMP Ngeri 1 Kedung galar kabupaten Ngawi tahun pelajaran 2015/2016

\section{Rancangan Penelitian}

Sesuai dengan jenis penelitian yang dipilih, yaitu penelitian tindakan, maka penelitian ini menggunakan model penelitian tindakan dari Arikunto, Suharsimi (1998) menjelaskan berbentuk spiral dari sklus yang satu ke siklus yang berikutnya. Setiap siklus meliputi planning (rencana), action (tindakan), observation (pengamatan), dan reflection (refleksi).

a. Rancangan/rencana awal, sebelum mengadakan penelitian peneliti menyusun rumusan masalah, tujuan dan membuat rencana tindakan, termasuk di dalamnya instrumen penelitian dan perangkat pembelajaran.

b. Kegiatan dan pengamatan, meliputi tindakan yang dilakukan oleh peneliti sebagai upaya membangun pemahaman konsep siswa serta mengamati hasil atau dampak dari diterapkannya metode pembelajaran model team games tournament. 
c. Refleksi, peneliti mengkaji, melihat dan mempertimbangkan hasil atau dampak dari tindakan yang dilakukan berdasarkan lembar pengamatan yang diisi oleh pengamat.

d. Rancangan/rencana yang direvisi, berdasarkan hasil refleksi dari pengamat membuat rancangan yang direvisi untuk dilaksanakan pada siklus berikutnya.

Observasi dibagi dalam tiga putaran, yaitu putaran 1, 2 dan 3, dimana masing putaran dikenai perlakuan yang sama dan membahas satu sub pokok bahasan yang diakhiri dengan tes formatif di akhir masing putaran. Dibuat dalam tiga putaran dimaksudkan untuk memperbaiki sistem pengajaranya.

\section{Instrumen Penelitian}

Instrumen yang digunakan dalam penelitian ini terdiri dari:

a. Silabus, yaitu seperangkat rencana dan pengaturan tentang kegiatan pembelajaran pengelolahan kelas, serta penilaian hasil belajar.

b. Rencana Pelajaran (RP), yaitu merupakan perangkat pembelajaran yang digunakan sebagai pedoman guru dalam mengajar dan disusun untuk tiap putaran. Masing-masing RP berisi kompetensi dasar, indikator pencapaian hasil belajar, tujuan pembelajaran khusus, dan kegiatan belajar mengajar.

c. Lembar Kegiatan Siswa, Lembar kegiatan ini yang dipergunakan siswa untuk membantu proses pengumpulan data hasil eksperimen.

d. Lembar Observasi Kegiatan Belajar Mengajar,

- Lembar observasi pengolahan metode pembelajaran kooperatif model TGT, untuk mengamati kemampuan guru dalam mengelola pembelajaran.
- Lembar observasi aktivitas siswa dan guru, untuk mengamati aktivitas siswa dan guru selama proses pembelajaran.

e. Tes formatif, Tes ini disusun berdasarkan tujuan pembelajaran yang akan dicapai, digunakan untuk mengukur kemampuan pemahaman konsep IPS Terpadu pokok bahasan system persamaan linier dua variable. Tes formatif ini diberikan setiap akhir putaran. Bentuk soal yang diberikan adalah pilihan ganda (objektif)

\section{Metode Pengumpulan Data}

Data-data yang diperlukan dalam penelitian ini diperoleh melalui observasi pengolahan metode pembelajaran kooperatif model TGT, observasi aktivitas siswa dan guru angket motivasi siswa, dan tes formatif.

\section{Teknik Analisis Data}

Untuk mengetahui keefektivan suatu metode dalam kegiatan pembelajaran perlu diadakan analisa data. Pada penelitian ini menggunakan teknik analisis deskriptif kualitatif, yaitu suatu metode penelitian yang bersifat menggambarkan kenyataan atau fakta sesuai dengan data yang diperoleh dengan tujuan untuk mengetahui prestasi belajar yang dicapai siswa juga untuk memperoleh respon siswa terhadap kegiatan pembelajaran serta aktivitas siswa selama proses pembelajaran.

\section{HASIL PENELITIAN DAN PEMBAHASAN}

Data penelitian yang diperoleh berupa hasil uji coba item butir soal, data observasi berupa pengamatan pengelolaan metode pembelajaran kooperatif model TGT dan pengamatan aktivitas siswa dan guru pada akhir pembelajaran, dan data tes formatif siswa pada setiap siklus.

Data hasil uji coba item butir soal digunakan untuk mendapatkan tes yang 
betul-betul mewakili apa yang diinginkan. Data ini selanjutnya dianalisis tingkat validitas, reliabilitas, taraf kesukaran, dan daya pembeda.

Data lembar observasi diambil dari dua pengamatan yaitu data pengamatan pengelolaan metode pembelajaran kooperatif model TGT yang digunakan untuk mengetahui pengaruh penerapan metode pembelajaran kooperatif model TGT dalam meningkatkan prestasi belajar siswa dan data pengamatan aktivitas siswa dan guru.

Data tes formatif untuk mengetahui peningkatan prestasi belajar siswa setelah diterapkan metode pembelajaran kooperatif model TGT.

1. Ketuntasan Hasil belajar Siswa

Melalui hasil penelitian ini menunjukkan bahwa pembelajaran kooperatif model TGT memiliki dampak positif dalam meningkatkan prestasi belajar siswa. Hal ini dapat dilihat dari semakin mantapnya pemahaman siswa terhadap materi yang disampaikan guru (ketuntasan belajar meningkat dari sklus I, II, dan III) yaitu masing-masing $61,7 \%, 88,5 \%$, dan 97,05\%.Pada siklus III ketuntasan belajar siswa secara klasikal telah tercapai.

2. Kemampuan Guru dalam Mengelola Pembelajaran

Berdasarkan analisis data, diperoleh aktivitas siswa dalam proses metode pembelajaran kooperatif model TGT dalam setiap siklus mengalami peningkatan. Hal ini berdampak positif terhadap prestasi belajar siswa yaitu dapat ditunjukkan dengan meningkatnya nilai rata-rata siswa pada setiap siklus yang terus mengalami peningkatan.

3. Aktivitas Guru dan Siswa Dalam Pembelajaran

Berdasarkan analisis data, diperoleh aktivitas siswa dalam proses pembelajaran fisika pokok bahasan system persamaan linier dua variable dengan metode pembelajaran kooperatif model TGT yang paling dominant adalah bekerja dengan menggunakan alat/media, mendengarkan/memperhatikan penjelasan guru, dan diskusi antar siswa/antara siswa dengan guru. Jadi dapat dikatakan bahwa aktivitas siswa dapat dikategorikan aktif.

Sedangkan untuk aktivitas guru selama pembelajaran telah melaksanakan langkah-langkah metode pembelajaran kooperatif model TGT dengan baik. Hal ini terlihat dari aktivitas guru yang muncul di antaranya aktivitas membimbing dan mengamati siswa dalam mengerjakan kegiatan LKS/menemukan konsep, menjelaskan materi yang sulit, memberi umpan balik/evaluasi/tanya jawab dimana prosentase untuk aktivitas di atas cukup besar.

\section{KESIMPULAN}

Dari hasil kegiatan pembelajaran yang telah dilakukan selama tiga siklus, dan berdasarkan seluruh pembahasan serta analisis yang telah dilakukan dapat disimpulkan sebagai berikut:

Pembelajaran dengan kooperatif model TGT memiliki dampak positif dalam meningkatkan motivasi dan kualitas pembelajaran belajar siswa yang ditandai dengan peningkatan ketuntasan belajar siswa

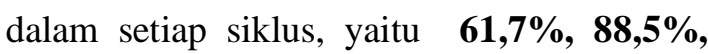
dan $\mathbf{9 7 , 0 5 \%}$.Penerapan metode pembelajaran kooperatif model TGT mempunyai pengaruh positif, yaitu dapat meningkatkan motivasi belajar siswa yang ditunjukan dengan hasil wawancara dengan beberapa siswa, rata-rata jawaban menyatakan bahwa siswa tertarik dan berminat dengan metode pembelajaran 
kooperatif model TGT sehingga mereka menjadi termotivasi untuk belajar.

\section{SARAN}

Dari hasil penelitian yang diperoleh dari uraian sebelumnya agar proses belajar mengajar IPS Terpadu lebih efektif dan lebih memberikan hasil yang optimal bagi siswa, maka disampaikan saran sebagai berikut:

1. Untuk melaksanakan metode pembelajaran kooperatif model TGT memerlukan persiapan yang cukup matang, sehingga guru harus mampu menentukan atau memilih topik yang benar-benar bisa diterapkan dengan model kooperatif model TGT dalam proses belajar mengajar sehingga diperoleh hasil yang optimal.

2. Dalam rangka meningkatkan prestasi belajar siswa, guru hendaknya lebih sering melatih siswa dengan berbagai metode pembelajaran, walau dalam taraf yang sederhana, dimana siswa nantinya dapat menemukan pengetahuan baru, memperoleh konsep dan keterampilan, sehingga siswa berhasil atau mampu memecahkan masalah-masalah yang dihadapinya.

3. Untuk penelitian yang serupa hendaknya dilakukan perbaikan-perbaikan agar diperoleh hasil yang lebih baik.

\section{REFERENSI}

Arikunto, Suharsimi. 1998. Prosedur Penelitian Suatu Pendekatan Praktek. Jakarta: Rineksa Cipta.

Djamarah, Syaiful Bahri. 2000. Strategi Belajar Mengajar. Jakarta: Rineksa Cipta.

Nur, Mohamad. 2005. Pembelajaran Kooperatif. Surabaya: Unesa.

Soekamto, Toeti. 1997. Teori Belajar dan Model Pembelajaran. Jakarta: PAUPPAI, Universitas Terbuka.

Wahyuni, Dwi. 2001. Studi Tentang Pembelajaran Kooperatif Terhadap Hasil Belajar Matematika. Malang: Program Sarjana Universitas Negeri Malang. 
WAHANA

e-ISSN: 2654-4954, p-ISSN: 0853-4403

Volume 71, Nomor 1, 1 Juni 2019 